\title{
Sample acidification significantly alters stable isotope ratios of sulfur in aquatic plants and animals
}

\author{
Rod M. Connolly ${ }^{1, *}$, Thomas A. Schlacher ${ }^{2}$ \\ ${ }^{1}$ Australian Rivers Institute - Coast and Estuaries, and School of Environment, Gold Coast Campus, Griffith University, \\ Queensland 4222, Australia \\ ${ }^{2}$ Faculty of Science, University of the Sunshine Coast, Maroochydore DC, Queensland 4558, Australia
}

\begin{abstract}
Sulfur stable isotopes are increasingly being used as tracers of material processing in studies of both modern and historical food webs. Preparation of plant and animal material for isotope analysis routinely includes steps that remove inorganic material not normally assimilated by consumers. Whereas acidification of samples is known to assist with this for some elements (carbon), it can produce unwanted effects for others (nitrogen). Here we tested the effects of acidification on sulfur isotopes by comparing isotope ratios of paired acidified and nonacidified samples of seagrass, epiphytic algae growing on seagrass and animal consumers (3 types of crustaceans: amphipods, copepods and isopods). Acid treatment resulted in significant losses of elemental sulfur from the tissues and changes in sulfur isotope ratios of samples. The artificial depletion of the heavy sulfur isotope decreased sulfur isotope ratios by $2.6 \%$ on average, and by as much as $7.0 \%$ in individual samples. Acidification of samples prior to sulfur isotope analysis results in invalid ratios and should not be used.
\end{abstract}

KEY WORDS: Acid digestion - Amino acids • Carbonate $\cdot$ DMSP $\cdot$ Seagrass $\cdot$ Stable isotope analysis

Resale or republication not permitted without written consent of the publisher

\section{INTRODUCTION}

Over the last 2 decades, the use of stable isotope (SI) analysis of the light elements hydrogen, carbon, nitrogen, oxygen and sulfur has developed into a near-universal tool in ecology, with applications encompassing fields of investigations and disciplines spanning the length and breadth of ecology. Within

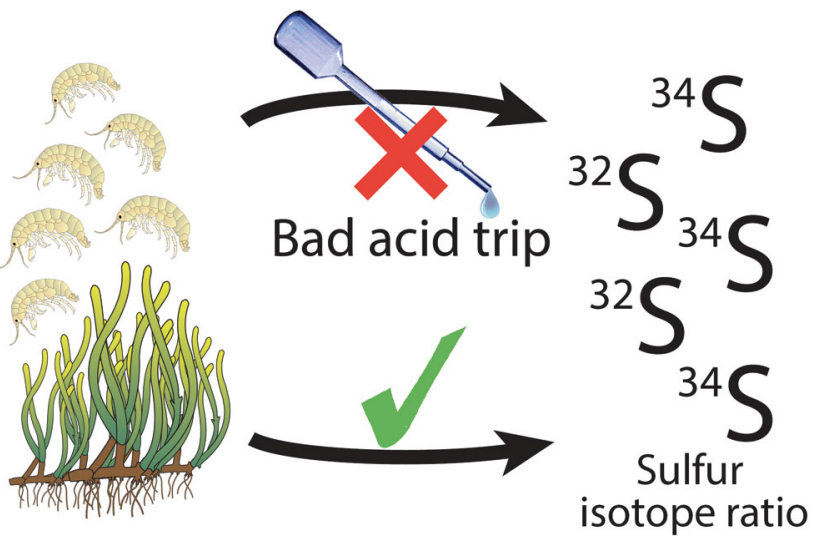

Acidification of samples prior to sulfur isotope analysis results in invalid ratios and should not be used.

Image: R. Connolly, Symbols: http://ian.umces.edu/symbols

the broader discipline of trophic ecology (sensu lato), SIs are commonly used to address 5 inter-related objectives: (1) to describe the structure of food webs and to identify the principal energetic pathways that make up food webs (Olson et al. 2010, Hilting et al. 2013), (2) to identify the main food categories of consumers (Winning et al. 1999, Oakes et al. 2010a, Le Pape et al. 2013, Vander Zanden et al. 2013), (3) to assess the probable inputs from different source materials to the diet of consumers (Melville \& Connolly 2005, Oakes et al. 2010b, Hyndes et al. 2013), (4) to estimate the length of food chains and trophic levels of consumer species (Post 2002, Layman et al. 2012) and (5) to reconstruct historical diets (Froehle et al. 2012). 
Movement and transformations of organic matter are key processes in ecosystems and food webs, and SI techniques are widely employed in this context to determine the provenance of organic matter and its subsequent biogeochemical transformations in detrital and sediment pools (Schlacher \& Wooldridge 1996, Connolly et al. 2005a, Rosenbauer et al. 2009). SI analysis is also employed to follow the exchanges of organic matter and nutrients between ecosystems and habitats (Gaston et al. 2006, Connolly et al. 2009, Fry 2011, Piovia-Scott et al. 2013), and to track animal movements (Rubenstein \& Hobson 2004). In pollution studies, SIs are effective chemical tracers to identify pollutant inputs and the movement of toxicants through food webs (Schlacher et al. 2007, Connolly et al. 2013, Jardine et al. 2013).
Naturally occurring SI ratios of S can be very useful as tracers of the fate of assimilated nutrients in aquatic food webs, particularly when the more routinely used elements, C and N, cannot resolve food web questions (Peterson \& Howarth 1987, Connolly et al. 2004). The relatively high variability of $\mathrm{S}$ isotope ratios over small spatial scales can help determine physiological and ecological processes in aquatic systems (Oakes \& Connolly 2004). In food web studies, $\mathrm{S}$ is particularly effective as a complementary element to $\mathrm{C}$ for source determination (Connolly et al. 2004)

Preparation of aquatic plants and animals for mass spectrometry can involve acidification of the samples (Table 1). Acid treatment is done to remove inorganic carbonate (contained in calcified biological struc-

Table 1. Examples of variability in sample preparation for sulfur stable isotope measurements of biological material used in food web studies with respect to acid treatment prior to mass spectrometry. The studies listed are illustrative and are not intended to cover the full range of the literature on $\delta^{34} \mathrm{~S}$ in aquatic plant and animal samples

\begin{tabular}{|c|c|c|}
\hline & Samples acidified & No acid treatment \\
\hline \multicolumn{3}{|l|}{ Primary producers } \\
\hline Benthic microalgae & $\begin{array}{l}\text { Weinstein et al. (2000), } \\
\text { Howe \& Simenstad (2011) }\end{array}$ & $\begin{array}{l}\text { Wainright et al. (2000), } \\
\text { Wilson et al. (2009) }\end{array}$ \\
\hline Phytoplankton & $\begin{array}{l}\text { Moncreiff \& Sullivan (2001), } \\
\text { Howe \& Simenstad (2011) }\end{array}$ & $\begin{array}{l}\text { Wainright et al. (2000), } \\
\text { Maier et al. (2011) }\end{array}$ \\
\hline $\begin{array}{l}\text { Macroalgae (e.g. Catenella, Cladophora, Dictyota, } \\
\text { Enteromorpha, Gracilaria, Rhizoclonum, Ulva) }\end{array}$ & $\begin{array}{l}\text { Currin et al. (2011), } \\
\text { Howe \& Simenstad (2011) }\end{array}$ & $\begin{array}{l}\text { Granek et al. (2009), } \\
\text { Wilson et al. (2009) }\end{array}$ \\
\hline $\begin{array}{l}\text { Marsh plants (e.g. Aster, Distichlis, Juncus, } \\
\text { Phragmites, Salicornia, Scirpus, Spartina, Typha) }\end{array}$ & $\begin{array}{l}\text { Attrill et al. (2009), } \\
\text { Howe \& Simenstad (2011) }\end{array}$ & $\begin{array}{l}\text { Wozniak et al. (2006), } \\
\text { Attrill et al. (2009) }\end{array}$ \\
\hline $\begin{array}{l}\text { Seagrass (e.g. Halodule, Halophila, Posidonia, } \\
\text { Ruppia, Syringodium, Thalassia, Zostera) }\end{array}$ & $\begin{array}{l}\text { Oakes \& Connolly (2004), } \\
\text { Hindell \& Warry (2010), } \\
\text { Currin et al. (2011) }\end{array}$ & $\begin{array}{l}\text { Holmer et al. (2009), } \\
\text { Wilson et al. (2009) }\end{array}$ \\
\hline $\begin{array}{l}\text { Mangroves (Avicennia, Bruguiera, } \\
\text { Rhizophora, Sonneratia) }\end{array}$ & $\begin{array}{l}\text { Newell et al. (1995), } \\
\text { Hindell \& Warry (2010) }\end{array}$ & $\begin{array}{l}\text { Benstead et al. (2006), } \\
\text { Granek et al. (2009) }\end{array}$ \\
\hline \multicolumn{3}{|l|}{ Consumers } \\
\hline Zooplankton & $\begin{array}{l}\text { Moncreiff \& Sullivan (2001), } \\
\text { Howe \& Simenstad (2011) }\end{array}$ & $\begin{array}{l}\text { Rissik et al. (2009), } \\
\text { Belicka et al. (2012) }\end{array}$ \\
\hline Sponges \& Cnidaria (corals) & Becker et al. (2009) & Granek et al. (2009) \\
\hline $\begin{array}{l}\text { Peracarid crustaceans (e.g. amphipods, } \\
\text { isopods, mysids, cumaceans) }\end{array}$ & $\begin{array}{l}\text { Becker et al. (2009), } \\
\text { Howe \& Simenstad (2011) }\end{array}$ & MacAvoy et al. (2002) \\
\hline $\begin{array}{l}\text { Decapod crustaceans (e.g. crabs, prawns, } \\
\text { shrimp, squat lobsters) }\end{array}$ & $\begin{array}{l}\text { Becker et al. (2009), } \\
\text { Howe \& Simenstad (2011) }\end{array}$ & $\begin{array}{l}\text { Leakey et al. (2008), } \\
\text { Wilson et al. (2009) }\end{array}$ \\
\hline $\begin{array}{l}\text { 'Worms' (e.g. polychaetes, } \\
\text { oligochaetes, flat worms, sipunculids) }\end{array}$ & $\begin{array}{l}\text { Newell et al. (1995), } \\
\text { Becker et al. (2009) }\end{array}$ & $\begin{array}{l}\text { MacAvoy et al.(2002), } \\
\text { Wilson et al. (2009) }\end{array}$ \\
\hline Molluscs (e.g. gastropods, bivalves, squid) & $\begin{array}{l}\text { Howe \& Simenstad (2011), } \\
\text { Belicka et al. (2012) }\end{array}$ & $\begin{array}{l}\text { Granek et al. (2009), } \\
\text { Wilson et al. (2009) }\end{array}$ \\
\hline $\begin{array}{l}\text { Echinoderms (e.g. sea urchins, brittle stars, } \\
\text { sea cucumbers) }\end{array}$ & $\begin{array}{l}\text { Newell et al. (1995), } \\
\text { Becker et al. (2009) }\end{array}$ & Vaslet et al. (2012) \\
\hline Fish & $\begin{array}{l}\text { Stribling \& Cornwell (1997), } \\
\text { Howe \& Simenstad (2011) }\end{array}$ & Belicka et al. (2012) \\
\hline Birds & Kwak \& Zedler (1997) & Moreno et al. (2011) \\
\hline Marine mammals & Barros et al. (2010) & Craig et al. (2006) \\
\hline
\end{tabular}


tures, such as shells and skeletons, or in sediments suspected to contaminate the samples) that would bias the isotope signal $\left(\delta^{13} \mathrm{C}\right)$ of organic matter that is of primary interest in food web studies. Treating samples with acids to remove carbonates can, however, have unintended consequences for nitrogen isotopes $\left(\delta^{15} \mathrm{~N}\right)$ that are altered during acid treatment (Bunn et al. 1995). This artefact introduced by acid treatment on $\delta^{15} \mathrm{~N}$ is variable and generally not predictable (Bosley \& Wainright 1999, Kennedy et al. 2005).

Sulfur isotopes have, historically, been more difficult and expensive to analyse than the routinely measured elements $\mathrm{C}$ and $\mathrm{N}$. The application of $\mathrm{S}$ isotopes in food web studies has increased markedly in recent years, a trend that tracks the wider adoption of isotope techniques in ecology (Fig. 1). However, there is no consistency among investigators with regards to acidification of sample material prior to the analytical determination of $\mathrm{S}$ isotope ratios $\left(\delta^{34} \mathrm{~S}\right)$, and no standard procedures exist regarding whether or not to acidify different types of biological materials (Table 1).

Acid treatment causes a bias in isotope analysis of $\mathrm{N}$, which occurs predominantly in proteins. Most organic $\mathrm{S}$ is also found in proteins, so acid treatment might also affect $\mathrm{S}$ ratios. With the increasing use of $\mathrm{S}$ isotopes, there are widespread inconsistencies in sample treatment (as seen in Table 1), making it important to know the effects of acidification on $\mathrm{S}$ isotopes. At present, no report has investigated any

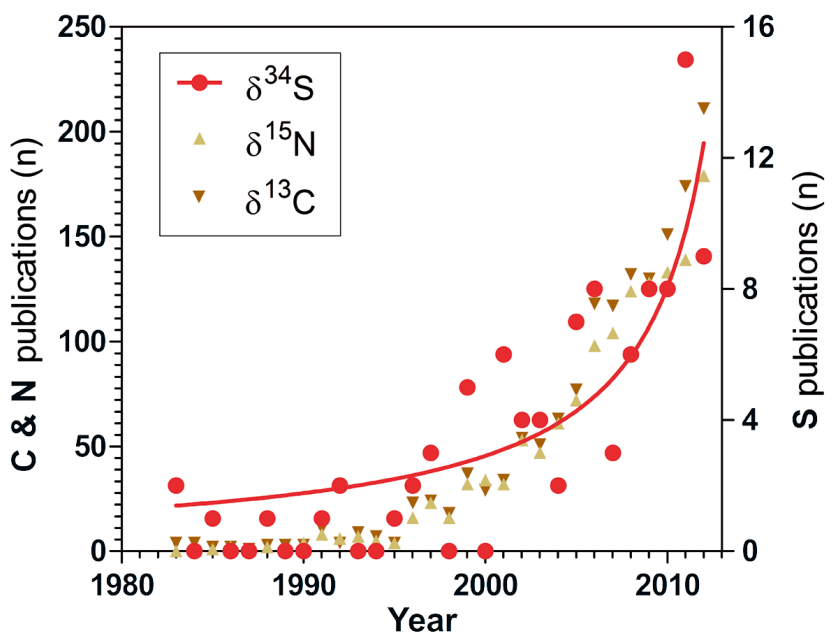

Fig. 1. Trend in the number of papers that used stable isotopes of sulfur, carbon or nitrogen in studies of food webs or trophic processes. Source: www.scopus.com. Search terms: ((\#\# AND isotope*) OR (\$ AND isotope *)) AND (foodweb* OR food web ${ }^{*}$ OR trophic), where \#\# = sulfur, or nitrogen, or carbon, and $\$=$ sulphur such possible effects. Here we determined acidtreatment effects on $\mathrm{S}$ isotope ratios in biological material representing key producers and consumers of an aquatic food web.

\section{MATERIALS AND METHODS}

Plants, algae and small animals associated with seagrass meadows were sampled on the east coast of the Gulf St Vincent in South Australia $\left(34^{\circ} 00^{\prime} \mathrm{S}\right.$, $\left.138^{\circ} 00^{\prime} \mathrm{E}\right)$, at sites previously used by Connolly et al. (2005b). We collected numerous samples of each organism type at multiple locations as part of a larger food web study, but for testing the effects of acidification, we selected the 3 samples from locations that provided the greatest quantity of material (especially important for samples of algae and small animal consumers). We used 3 species of seagrass from shallow coastal waters (Posidonia australis, P. sinuosa, Zostera muelleri). Each seagrass sample consisted of 3 leaves from different shoots, scraped clean of conspicuous epiphytic algae with a razor blade and rinsed in distilled water (see Guest et al. 2004). For algae samples, we used epiphytic macroalgae removed from 2 of the seagrass species, $P$. australis and $Z$. muelleri. These were short, fine filaments comprising a mixture of green, red and brown algae. We used 3 types of crustaceans, collected from the seagrass canopy using fine-mesh sweep nets: gammarid amphipods (multiple species), harpacticoid copepods (multiple species) and isopods (Platynympha longicaudata). Samples consisted of numerous individual animals (amphipods $>20$, copepods $>100$, isopods $>5$ ). For each of these 8 organism types, we had 3 replicate samples. Sample material was dried at $60^{\circ} \mathrm{C}$ to constant weight, ground to a fine powder using mortar and pestle and split into 2 aliquots (both $>5 \mathrm{mg}$ ), one for analysis without any further processing, the other for analysis after acid treatment.

The procedure for acid treatment consisted of slowly adding drops of $\mathrm{HCl}(1 \mathrm{M})$ to dry, powdered material in glass vials until all gas production had ceased. We elected not to further rinse the acidified sample with distilled water before re-drying since it has been shown that, for $\mathrm{C}$ isotopes, rinsing can in itself affect isotope ratios (Mateo et al. 2008).

The ${ }^{34} \mathrm{~S}:{ }^{32} \mathrm{~S}$ ratio was calculated as the relative per mille $(\%)$ difference between the sample and a recognised international standard (Canyon Diablo Troilite) at the Iso-Analytical Laboratory (UK) on a continuous-flow isotope ratio mass spectrometer. From 3 to $20 \mathrm{mg}$ of each sample (giving $40 \mu \mathrm{g}$ of $\mathrm{S}$ ) 

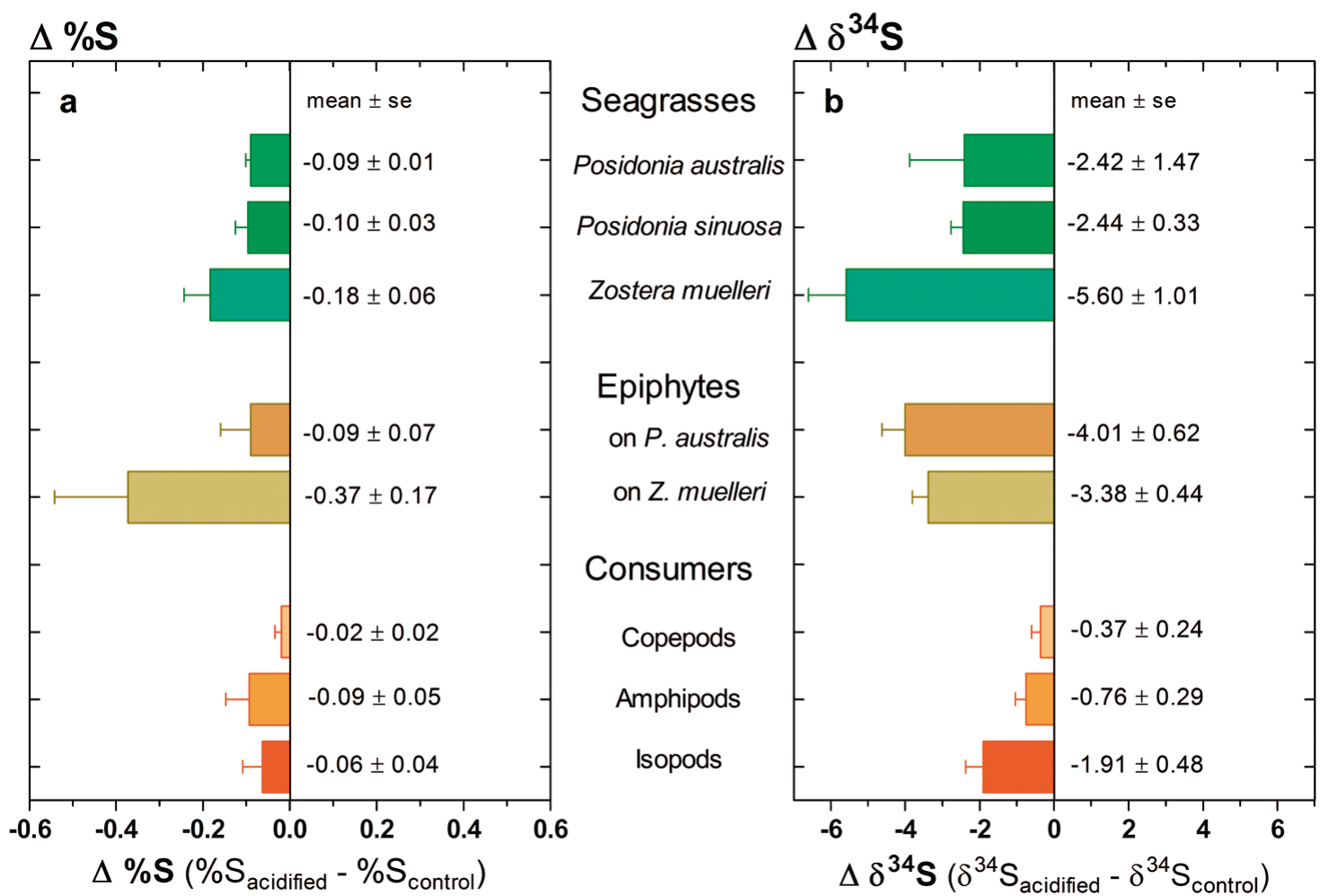

Fig. 2. Effects of acid treatment on (a) the elemental sulfur content and (b) the sulfur isotope ratio $\left(\delta^{34} \mathrm{~S}\right)$ in biological sample material from seagrass meadows (epiphytes refers to algae growing on seagrass leaves). Negative values denote (a) lower concentrations of sulfur in the tissue following acidification, or (b) lighter isotope ratios resulting from depletion of ${ }^{34} \mathrm{~S}$ following acid treatment

was weighed into tin capsules and vanadium pentoxide catalyst added. Analysis of multiple sub-samples $(\mathrm{n}=3)$ demonstrated good precision (SE 0.14\%o).

\section{RESULTS}

Acid treatment significantly altered $\mathrm{S}$ isotope ratios, causing a shift towards more depleted $\delta^{34} \mathrm{~S}$ values (paired $t$-test, $\mathrm{p}<0.001$; Fig. 2b). The mean \pm SE shift across all groups was $-2.61 \pm 0.40 \%$, with individual samples becoming depleted by up to about $7 \%$. Changes in $\delta^{34} \mathrm{~S}$ attributable to sample treatment were greatest in the seagrass Zostera muelleri, followed by epiphytes and the 2 species of Posidonia (Fig. 2b). Although $\mathrm{S}$ isotope ratios in consumers were, on average, comparatively less affected by acid treatment, individual samples of isopods were depleted
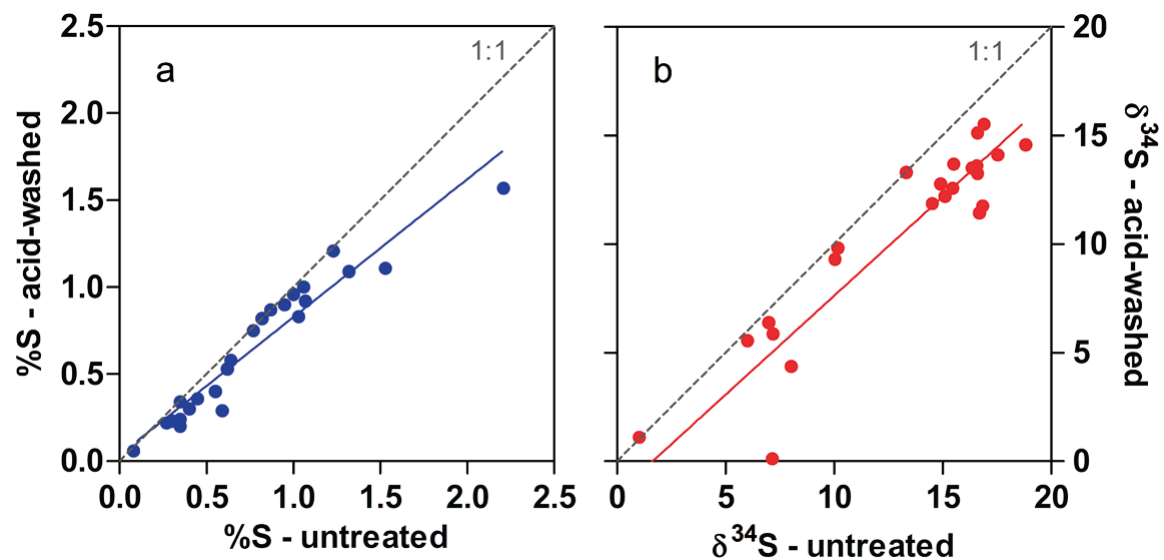

Fig. 3. Relationship between (a) sulfur content and (b) isotope ratios $\left(\delta^{34} \mathrm{~S}\right)$ in acidified samples ( $y$-axis) compared with paired aliquots that had not been exposed to acids ( $x$-axis). Line of best fit is linear regression, significant in both panels ( $p<0.05$ ) 
by up to nearly $3 \%$ in $\delta^{34}$ S following acidification. When examined over the full range of $\delta^{34} \mathrm{~S}$ values obtained, isotope shifts did not vary systematically in relation to the original $\delta^{34} \mathrm{~S}$ value of the untreated sample: relatively light samples were just as likely to become depleted due to acid treatment as more enriched samples (Fig. 3b).

The elemental S content of sample materials averaged $0.78 \pm 0.10 \%$. Epiphytic algae generally had the highest mean S content: it was $1.60 \pm 0.33 \%$ in samples collected from the seagrass Zostera muelleri and $1.11 \pm 0.17 \%$ in samples obtained from Posidonia australis. The lowest $\mathrm{S}$ content was recorded in the tissues of the 3 seagrass species ( $Z$. muelleri: $0.51 \pm$ $0.06 \%$; P. australis: $0.42 \pm 0.10 \%$; $P$. sinuosa: $0.36 \pm$ $0.05 \%)$. S concentrations in animal tissues were intermediate between epiphytes and seagrasses (isopods: $0.98 \pm 0.06 \%$; amphipods: $0.58 \pm 0.28 \%$; copepods: $0.71 \pm 0.18 \%$ ).

Acidification resulted in a significant decrease in tissue $\mathrm{S}$ content (paired $t$-test, $\mathrm{p}<0.001$; Fig. 2a). Concentrations of elemental $\mathrm{S}$ in acid-treated material were lower by 0.02 to $0.64 \%$ (mean decrease: $-0.13 \pm 0.03 \%$; Fig. 2). These losses represent, on average, $17 \%$ of the total elemental $\mathrm{S}$ contained in the tissues before acid treatment; in individual samples, acidification removed up to half of the tissue $S$ pool. The effects of acid-digestion on S concentrations were greatest in epiphytes of Zostera muelleri, followed by the tissues of the seagrasses $Z$. muelleri and Posidonia sinuosa. Loss of S during acidification was largely proportional to the original S content of the samples, albeit showing a slight tendency for some particularly S-rich samples to lose more S (Fig. 3a).

\section{DISCUSSION}

Inorganic compounds are not usually assimilated by consumers, and thus cannot affect the isotope ratios of consumers. Accurate modelling of nutrition pathways in food webs therefore relies on obtaining the isotope ratio of only the organic fraction of biological samples. Some components of aquatic food webs are either small, precluding simple excision of muscle tissue, or in the case of plants, are difficult to separate from associated sediment, or have attached biota that have carbonate skeletons. Such samples are normally acidified during laboratory processing to remove the inorganic $\mathrm{C}$ prior to combustion for mass spectrometry. A critical assumption of this acidification step is that it removes inorganic $\mathrm{C}$, but does not cause substantial losses of $\mathrm{C}, \mathrm{N}$ or $\mathrm{S}$ bound up in the organic fraction. By contrast, we observed losses of $\mathrm{S}$ in all tissue types following acidification. Similar decreases in elemental C attributable to acid treatment have been reported for phytoplankton (King et al. 1998), littoral invertebrates (Serrano et al. 2008, Vafeiadou et al. 2013) and marine sediments (Lohse et al. 2000), and have been used to indicate leaching or volatilisation of organic matter beyond the intended removal of inorganic $\mathrm{C}$.

The general effect of acid treatment was a shift towards more negative $\delta^{34} \mathrm{~S}$ values in all tissue types examined. The magnitude of this method-related bias was variable, however, both within and among the categories of tissues tested. This variability in observed effect size (notwithstanding its overall strength and consistent direction) precludes the proposition of an 'acid correction term' that may be more widely applicable. Extrapolation of results beyond the taxa tested here should not be assumed and would require further testing. In addition, shifts in $\delta^{34} \mathrm{~S}$ caused by acid treatment were only weakly correlated with corresponding shifts in the elemental $\mathrm{S}$ content of the samples $(\mathrm{r}=0.37, \mathrm{p}=0.07)$; they were also not significantly correlated with either the $\mathrm{S}$ content $(\mathrm{r}=-0.13, \mathrm{p}=0.53)$ or the $\mathrm{S}$ isotope ratio $(\mathrm{r}=$ $-0.22, p=0.29$ ) of the untreated sample. Thus, neither the chemical composition nor the isotopic signature of untreated samples is an adequate or useful predictor of the magnitude of expected acid-related shifts in $\delta^{34} \mathrm{~S}$.

Acid effects on stable $\mathrm{C}$ isotope ratios have been reported for a range of biological materials (e.g. Jacob et al. 2005, Jaschinski et al. 2008, Mateo et al. 2008). However, no unequivocal explanation of the mechanisms that produce the observed shifts in isotope ratios has been reported in the literature. Processes that have been posited as mechanisms for isotopic change and fractionation of $\mathrm{C}$ and $\mathrm{N}$ caused by acid treatment-and which may equally well apply for $\mathrm{S}$-include the following: (1) loss of acid-soluble organic matter during carbonate dissolution ('solubilisation') and leaching from tissues (Fernandes \& Krull 2008, Serrano et al. 2008, Brodie et al. 2011); (2) volatilisation of organic compounds (Lohse et al. 2000, Brodie et al. 2011); (3) structural disintegrations of cells and tissues and break-up of complex compounds that are subsequently lost in sample rinses (Mateo et al. 2008); and (4) selective preservation or loss of organic matter and compounds with isotopically different signatures (Benner et al. 1987, Brodie et al. 2011). A fifth factor, loss of material during sample transfers, filtrations, rinses or decanting following acid treatment (Fernandes \& Krull 2008, Brodie et al. 2011), is un- 
likely to have been important in the current study since we did not rinse or wash samples with water.

Sulfur is a vital constituent of key structural and functional molecules such as amino acids, sulfolipids and cofactors such as vitamins and enzymes (Trust \& Fry 1992, Brosnan \& Brosnan 2006). The S content of plants typically ranges between 0.1 and $1.5 \%$ by dry weight (Trust \& Fry 1992). In marine taxa, $\mathrm{S}$ is an essential element in dimethylsulfoniopropionate (DMSP), a secondary metabolite that is widespread in algae, vascular plants, invertebrates and vertebrates (Van Alstyne \& Puglisi 2007). DMSP has a wide range of ecophysiological functions, being an antioxidant, a cryoprotectant, an osmolyte, a precursor to an activated defence system and a source of $\mathrm{S}$ for marine bacterioplankton (Van Alstyne \& Puglisi 2007, Oduro et al. 2012). The $\mathrm{S}$ isotope ratio of DMSP in marine algae may be depleted in ${ }^{34} \mathrm{~S}$ relative to other cellular components, since it is has different biochemical pathways to formation. We found no direct determinations of whether the $\mathrm{S}$ isotope ratio of DMSP differs from those of other cellular components, although it is known to differ from that in source seawater sulfate by 1 to $3 \%$ (Oduro et al. 2012). Selective removal of DSMP during acid treatments remains as an untested but possible mechanism for the isotopic changes that we observed (Figs. $1 \& 2$ ).

\section{CONCLUSIONS}

Acid treatment of biological material prior to isotope ratio mass spectrometry results in significant changes to the S content and isotopic composition of the samples. These changes represent a method bias that introduces avoidable error to food web analyses using SIs of $\mathrm{S}$ as chemical tracers. Thus, acid treatment should be avoided as a pre-analysis step in the measurement of $\delta^{34} \mathrm{~S}$, and determinations should made on untreated aliquots for materials where carbonate removal by acids is required for carbon isotope analysis.

Acknowledgements. We thank E. Carr, R. Duffy, D. Gorman and J. Hindell for field and laboratory assistance, and the Coopers family for support in South Australia. The work was funded by the Australian Research Council and the Fisheries Research and Development Corporation.

\section{LITERATURE CITED}

Attrill MJ, Rundle SD, Fraser A, Power M (2009) Oligochaetes as a possible entry route for terrigenous organic carbon into estuarine benthic food webs. Mar Ecol Prog Ser 384:147-157
Barros NB, Ostrom PH, Stricker CA, Wells RS (2010) Stable isotopes differentiate bottlenose dolphins off west-central Florida. Mar Mamm Sci 26:324-336

Becker EL, Cordes EE, Macko SA, Fisher CR (2009) Importance of seep primary production to Lophelia pertusa and associated fauna in the Gulf of Mexico. Deep-Sea Res I Oceanogr Res Pap 56:786-800

Belicka LL, Burkholder D, Fourqurean JW, Heithaus MR, Macko SA, Jaffe R (2012) Stable isotope and fatty acid biomarkers of seagrass, epiphytic, and algal organic matter to consumers in a pristine seagrass ecosystem. Mar Freshw Res 63:1085-1097

Benner R, Fogel ML, Sprague EK, Hodson RE (1987) Depletion of $\mathrm{C}$ in lignin and its implications for stable carbon isotope studies. Nature 329:708-710

Benstead JP, March JG, Fry B, Ewel KC, Pringle CM (2006) Testing Isosource: stable isotope analysis of a tropical fishery with diverse organic matter sources. Ecology 87: 326-333

Bosley KL, Wainright SC (1999) Effects of preservatives and acidification on the stable isotope ratios $\left({ }^{15} \mathrm{~N}:{ }^{14} \mathrm{~N},{ }^{13} \mathrm{C}:{ }^{12} \mathrm{C}\right)$ of two species of marine animals. Can J Fish Aquat Sci 56:2181-2185

Brodie CR, Leng MJ, Casford JSL, Kendrick CP, Lloyd JM, Yongqiang Z, Bird MI (2011) Evidence for bias in C and $\mathrm{N}$ concentrations and $\delta^{13} \mathrm{C}$ composition of terrestrial and aquatic organic materials due to pre-analysis acid preparation methods. Chem Geol 282:67-83

Brosnan JT, Brosnan ME (2006) The sulfur-containing amino acids: an overview. J Nutr 136:1636S-1640S

Bunn SE, Loneragan NR, Kempster MA (1995) Effects of acid washing on stable isotope ratios of $\mathrm{C}$ and $\mathrm{N}$ in penaeid shrimp and seagrass: implications for food-web studies using multiple stable isotopes. Limnol Oceanogr 40:622-625

Connolly RM, Guest MA, Melville AJ, Oakes JM (2004) Sulfur stable isotopes separate producers in marine foodweb analysis. Oecologia 138:161-167

Connolly RM, Gorman JD, Guest MA (2005a) Movement of carbon among estuarine habitats and its assimilation by invertebrates. Oecologia 144:684-691

> Connolly RM, Hindell JS, Gorman D (2005b) Seagrass and epiphytic algae support nutrition of a fisheries species, Sillago schomburgkii, in adjacent intertidal habitats. Mar Ecol Prog Ser 286:69-79

> Connolly RM, Schlacher TA, Gaston TF (2009) Stable isotope evidence for trophic subsidy of coastal benthic fisheries by river discharge plumes off small estuaries. Mar Biol Res 5:164-171

> Connolly RM, Gorman D, Hindell JS, Kildea TN, Schlacher TA (2013) High congruence of isotope sewage signals in multiple marine taxa. Mar Pollut Bull 71:152-158

> Craig OE, Ross R, Andersen SH, Milner N, Bailey GN (2006) Focus: sulphur isotope variation in archaeological marine fauna from northern Europe. J Archaeol Sci 33:1642-1646

> Currin CA, Levin LA, Talley TS, Michener R, Talley D (2011) The role of cyanobacteria in Southern California salt marsh food webs. Mar Ecol 32:346-363

- Fernandes M, Krull E (2008) How does acid treatment to remove carbonates affect the isotopic and elemental composition of soils and sediments? Environ Chem 5:33-39

Froehle AW, Kellner CM, Schoeninger MJ (2012) Multivariate carbon and nitrogen stable isotope model for the reconstruction of prehistoric human diet. Am J Phys Anthropol 147:352-369 
Fry B (2011) Mississippi River sustenance of brown shrimp (Farfantepenaeus aztecus) in Louisiana coastal waters. Fish Bull 109:147-161

Gaston TF, Schlacher TA, Connolly RM (2006) Flood discharges of a small river into open coastal waters: plume traits and material fate. Estuar Coast Shelf Sci 69:4-9

> Granek EF, Compton JE, Phillips DL (2009) Mangroveexported nutrient incorporation by sessile coral reef invertebrates. Ecosystems 12:462-472

Guest MA, Connolly RM, Loneragan NR (2004) Within and among-site variability in $\delta^{13} \mathrm{C}$ and $\delta^{15} \mathrm{~N}$ for three estuarine producers, Sporobolus virginicus, Zostera capricorni, and epiphytes of Z. capricorni. Aquat Bot 79:87-94

> Hilting AK, Currin CA, Kosaki RK (2013) Evidence for benthic primary production support of an apex predatordominated coral reef food web. Mar Biol 160:1681-1695

> Hindell JS, Warry FY (2010) Nutritional support of estuary perch (Macquaria colonorum) in a temperate Australian inlet: evaluating the relative importance of invasive Spartina. Estuar Coast Shelf Sci 90:159-167

> Holmer M, Baden S, Boström C, Moksnes PO (2009) Regional variation in eelgrass (Zostera marina) morphology, production and stable sulfur isotopic composition along the Baltic Sea and Skagerrak coasts. Aquat Bot 91: 303-310

> Howe ER, Simenstad CA (2011) Isotopic determination of food web origins in restoring and ancient estuarine wetlands of the San Francisco Bay and Delta. Estuar Coasts 34:597-617

Hyndes GA, Nagelkerken I, McLeod RJ, Connolly RM, Lavery PS, Vanderklift MA (2013) Mechanisms and ecological role of carbon transfer within coastal seascapes. Biol Rev doi:10.1111/brv.12055

> Jacob U, Mintenbeck K, Brey T, Knust R, Beyer K (2005) Stable isotope food web studies: a case for standardized sample treatment. Mar Ecol Prog Ser 287:251-253

> Jardine TD, Kidd KA, O' Driscoll N (2013) Food web analysis reveals effects of $\mathrm{pH}$ on mercury bioaccumulation at multiple trophic levels in streams. Aquat Toxicol 132133:46-52

> Jaschinski S, Hansen T, Sommer U (2008) Effects of acidification in multiple stable isotope analyses. Limnol Oceanogr Methods 6:12-15

Kennedy P, Kennedy H, Papadimitriou S (2005) The effect of acidification on the determination of organic carbon, total nitrogen and their stable isotopic composition in algae and marine sediment. Rap Commun Mass Spectrom 19:1063-1068

King P, Kennedy H, Newton PP, Jickells TD and others (1998) Analysis of total and organic carbon and total nitrogen in settling oceanic particles and a marine sediment: an inter-laboratory comparison. Mar Chem 60:203-216

Kwak TJ, Zedler JB (1997) Food web analysis of southern California coastal wetlands using multiple stable isotopes. Oecologia 110:262-277

Layman CA, Araujo MS, Boucek R, Hammerschlag-Peyer CM and others (2012) Applying stable isotopes to examine food-web structure: an overview of analytical tools. Biol Rev Camb Philos Soc 87:545-562

> Le Pape O, Modéran J, Beaunée G, Riera P and others (2013) Sources of organic matter for flatfish juveniles in coastal and estuarine nursery grounds: a meta-analysis for the common sole (Solea solea) in contrasted systems of Western Europe. J Sea Res 75:85-95
Leakey CDB, Attrill MJ, Jennings S, Fitzsimons MF (2008) Stable isotopes in juvenile marine fishes and their invertebrate prey from the Thames Estuary, UK, and adjacent coastal regions. Estuar Coast Shelf Sci 77:513-522

> Lohse L, Kloosterhuis RT, de Stigter HC, Helder W, van Raaphorst W, van Weering TCE (2000) Carbonate removal by acidification causes loss of nitrogenous compounds in continental margin sediments. Mar Chem 69: 193-201

> MacAvoy SE, Carney RS, Fisher CR, Macko SA (2002) Use of chemosynthetic biomass by large, mobile, benthic predators in the Gulf of Mexico. Mar Ecol Prog Ser 225: 65-78

> Maier GO, Toft JD, Simenstad CA (2011) Variability in isotopic $\left(\delta^{13} \mathrm{C}, \delta^{15} \mathrm{~N},{ }^{34} \mathrm{~S}\right)$ composition of organic matter contributing to detritus-based food webs of the Columbia River estuary. Northwest Sci 85:41-54

Mateo MA, Serrano O, Serrano L, Michener RH (2008) Effects of sample preparation on stable isotope ratios of carbon and nitrogen in marine invertebrates: implications for food web studies using stable isotopes. Oecologia 157:105-115

Melville AJ, Connolly RM (2005) Food webs supporting fish over subtropical mudflats are based on transported organic matter not in situ microalgae. Mar Biol 148: 363-371

> Moncreiff CA, Sullivan MJ (2001) Trophic importance of epiphytic algae in subtropical seagrass beds: evidence from multiple stable isotope analyses. Mar Ecol Prog Ser 215:93-106

Moreno R, Jover L, Velando A, Munilla I, Sanpera C (2011) Influence of trophic ecology and spatial variation on the isotopic fingerprints of seabirds. Mar Ecol Prog Ser 442:229-239

Newell RIE, Marshall N, Sasekumar A, Chong VC (1995) Relative importance of benthic microalgae, phytoplankton, and mangroves as sources of nutrition for penaeid prawns and other coastal invertebrates from Malaysia. Mar Biol 123:595-606

> Oakes JM, Connolly RM (2004) Causes of sulfur isotope variability in the seagrass, Zostera capricorni. J Exp Mar Biol Ecol 302:153-164

> Oakes JM, Connolly RM, Revill AT (2010a) Isotope enrichment in mangrove forests separates microphytobenthos and detritus as carbon sources for animals. Limnol Oceanogr 55:393-402

> Oakes JM, Eyre BD, Ross DJ, Turner SD (2010b) Stable isotopes trace estuarine transformations of carbon and nitrogen from primary and secondary treated paper and pulp mill effluent. Environ Sci Technol 44:7411-7417

> Oduro H, Van Alstyne KL, Farquhar J (2012) Sulfur isotope variability of oceanic DMSP generation and its contributions to marine biogenic sulfur emissions. Proc Natl Acad Sci USA 109:9012-9016

> Olson RJ, Popp BN, Graham BS, López-Ibarra GA and others (2010) Food-web inferences of stable isotope spatial patterns in copepods and yellowfin tuna in the pelagic eastern Pacific Ocean. Prog Oceanogr 86:124-138

> Peterson BJ, Howarth RW (1987) Sulfur, carbon, and nitrogen isotopes used to trace organic matter flow in the saltmarsh estuaries of Sapelo Island, Georgia. Limnol Oceanogr 32:1195-1213

Piovia-Scott J, Spiller DA, Takimoto G, Yang LH, Wright AN, Schoener TW (2013) The effect of chronic seaweed subsidies on herbivory: plant-mediated fertilization path- 
way overshadows lizard-mediated predator pathways. Oecologia 172:1129-1135

Post DM (2002) The long and short of food-chain length. Trends Ecol Evol 17:269-277

Rissik D, Shon EH, Newell B, Baird ME, Suthers IM (2009) Plankton dynamics due to rainfall, eutrophication, dilution, grazing and assimilation in an urbanized coastal lagoon. Estuar Coast Shelf Sci 84:99-107

Rosenbauer RJ, Swarzenski PW, Kendall C, Orem WH, Hostettler FD, Rollog ME (2009) A carbon, nitrogen, and sulfur elemental and isotopic study in dated sediment cores from the Louisiana Shelf. Geo-Mar Lett 29:415-429

Rubenstein DR, Hobson KA (2004) From birds to butterflies: animal movement patterns and stable isotopes. Trends Ecol Evol 19:256-263

Schlacher TA, Wooldridge TH (1996) Origin and trophic importance of detritus-evidence from stable isotopes in the benthos of a small, temperate estuary. Oecologia 106:382-388

Schlacher TA, Mondon JA, Connolly RM (2007) Estuarine fish health assessment: evidence of wastewater impacts based on nitrogen isotopes and histopathology. Mar Pollut Bull 54:1762-1776

Serrano O, Serrano L, Mateo MA, Colombini I, Chelazzi L, Gagnarli E, Fallaci M (2008) Acid washing effect on elemental and isotopic composition of whole beach arthropods: implications for food web studies using stable isotopes. Acta Oecol 34:89-96

Stribling JM, Cornwell JC (1997) Identification of important primary producers in a Chesapeake Bay tidal creek system using stable isotopes of carbon and sulfur. Estuaries 20:77-85

> Trust BA, Fry B (1992) Stable sulphur isotopes in plants: a review. Plant Cell Environ 15:1105-1110

> Vafeiadou AM, Adao H, de Troch M, Moens T (2013) Sample acidification effects on carbon and nitrogen stable

Editorial responsibility: Edward Durbin, Narragansett, Rhode Island, USA isotope ratios of macrofauna from a Zostera noltii bed. Mar Freshw Res 64:741-745

Van Alstyne KL, Puglisi MP (2007) DMSP in marine macroalgae and macroinvertebrates: distribution, function, and ecological impacts. Aquat Sci 69:394-402

Vander Zanden HB, Arthur KE, Bolten AB, Popp BN and others (2013) Trophic ecology of a green turtle breeding population. Mar Ecol Prog Ser 476:237-249

Vaslet A, Phillips DL, France C, Feller IC, Baldwin CC (2012) The relative importance of mangroves and seagrass beds as feeding areas for resident and transient fishes among different mangrove habitats in Florida and Belize: evidence from dietary and stable isotope analyses. J Exp Mar Biol Ecol 434-435:81-93

> Wainright SC, Weinstein MP, Able KW, Currin CA (2000) Relative importance of benthic microalgae, phytoplankton and the detritus of smooth cordgrass Spartina alterniflora and the common reed Phragmites australis to brackish-marsh food webs. Mar Ecol Prog Ser 200: 77-91

Weinstein MP, Litvin SY, Bosley KL, Fuller CM, Wainright SC (2000) The role of tidal salt marsh as an energy source for marine transient and resident finfishes: a stable isotope approach. Trans Am Fish Soc 129:797-810

Wilson RM, Chanton J, Lewis G, Nowacek D (2009) Combining organic matter source and relative trophic position determinations to explore trophic structure. Estuar Coast 32:999-1010

Winning MA, Connolly RM, Loneragan NR, Bunn SE (1999) ${ }^{15} \mathrm{~N}$ enrichment as a method of separating the isotopic signatures of seagrass and its epiphytes for food web analysis. Mar Ecol Prog Ser 189:289-294

Wozniak AS, Roman CT, Wainright SC, McKinney RA, James-Pirri MJ (2006) Monitoring food web changes in tide-restored salt marshes: a carbon stable isotope approach. Estuar Coast 29:568-578

Submitted: July 3, 2013; Accepted: September 10, 2013 Proofs received from author(s): October 18, 2013 